\title{
30 years follow-up and increased risks of breast cancer and leukaemia after long-term low-dose-rate radiation exposure
}

\author{
Wan-Hua Hsieh ${ }^{1,7}$, I-Feng Lin ${ }^{2,7}$, Jung-Chun $\mathrm{Ho}^{3,4}$ and Peter Wushou Chang ${ }^{\star, 5,6}$ \\ ${ }^{1}$ Department of Public Health, Tzu Chi University, Hualien 970, Taiwan; ${ }^{2}$ Institute of Public Health, School of Medicine, National \\ Yang-Ming University, Taipei 112, Taiwan; ${ }^{3}$ School of Oral Hygiene, Taipei Medical University, Taipei 110, Taiwan; ${ }^{4}$ Department of \\ Nursing, Kang-Ning University, Taipei 114, Taiwan; ${ }^{5}$ Taipei Hospital, Ministry of Health and Welfare, New Taipei City 242, Taiwan \\ and ${ }^{6}$ National Health Research Institute, Miaoli 350, Taiwan
}

Background: The current study followed-up site-specific cancer risks in an unique cohort with 30 years' follow-up after long-term low-dose-rate radiation exposure in Taiwan.

Methods: 6242 Taiwanese people received extra exposure in residential and school buildings constructed with Co-60contaminated steel from 1982 until informed and relocated in early 1990s. The additional doses received have been estimated. During 1983-2012, 300 cancer cases were identified through the national cancer registry in Taiwan, 247 cases with minimum latent periods from initial exposure. The hazard ratios (HR) of site-specific cancers were estimated with additional cumulative exposure estimated individually.

Results: Dose-dependent risks were statistically significantly increased for leukaemia excluding chronic lymphocytic leukaemia ( $\left.\mathrm{HR}_{100 \mathrm{msv}} 1.18 ; 90 \% \mathrm{Cl} 1.04-1.28\right)$, breast cancers ( $\left.\mathrm{HR}_{100 \mathrm{msv}} 1.11 ; 90 \% \mathrm{Cl} 1.05-1.20\right)$, and all cancers ( $\mathrm{HR}_{100 \mathrm{msv}} 1.05 ; 90 \% \mathrm{Cl} 1.0-1.08$, $P=0.04)$. Women with an initial age of exposure lower than 20 were shown with dose response increase in breast cancers risks $\left(\mathrm{HR}_{100 \mathrm{mSv}}\right.$ 1.38; $\left.90 \% \mathrm{Cl} 1.14-1.60 ; P=0.0008\right)$.

Conclusions: Radiation exposure before age 20 was associated with a significantly increased risk of breast cancer at much lower radiation exposure than observed previously.

The effects of acute radiation exposure on cancer risks have been well established in non-occupational exposed general populations (Preston et al, 1994, 2007; Ozasa et al, 2012; Hsu et al, 2013; Leuraud et al, 2015). Although occupational radiation hazards often involve long-term low-level exposure in adults, healthy worker effects cannot be neglected. Recent studies from protracted low-level radiation exposure have observed increased risks on leukaemia incidence, such as in the Techa River Cohort study (Krestinina et al, 2013; Richardson et al, 2015) and the International Nuclear WORKers Study (INWORKS; Krestinina et al, 2013). Similar to these results were solid cancer mortality (Schonfeld et al, 2013) and solid cancer incidence after adjusted smoking among the Techa Tiver Cohort study (Davis et al, 2015). The risks of prolonged low-level ionising radiation on site-specific cancers in the general population remain to be further examined.

In late 1982, over 200 schools and residential buildings constructed in Taiwan accidentally used $>20000$ tons of steel rebar contaminated with cobalt-60 (Chang, 1993, 1997; Chang and Kau, 1993). It was not until early 1992 that residents and students who resided or studied in these buildings were identified and

\footnotetext{
*Correspondence: Dr PW Chang; E-mail: peter.chang3@gmail.com

${ }^{7}$ These authors made equal contributions to the work.
}

Received 20 April 2017; revised 19 August 2017; accepted 7 September 2017; published online 3 October 2017

(C) 2017 Cancer Research UK. All rights reserved 0007-0920/17 
informed as exposed to excessive cumulative radiation. The governmental regulator conducted a nationwide survey of buildings suspected to contain contaminated steel, whereas a radiationcontaminated buildings (RCB) epidemiological study registered $\sim 10000$ citizens having received protracted low-dose-rate radiation exposure since 1982 . However, when the study started in late 1992, some of them and particularily students had already leaved and without adequate information for exposure assessment. Eventually, 6242 were with adequate information for cumulative exposure assessment system Taiwan Cumulative Dose (TCD) established on an individual basis. The TCD integrated the time activity analysis of each cohort members, with detailed history of occupancy duration in each radioactive area of the buildings and area-specific radiation exposure to the whole body. Cohort members recalled detailed information about previous occupancy on representative spots accordingly, with temporal exposures considering half-life of radioactive decay, that is, 5.27 years for Co60 . The TCD had been employed in several related studies (Wang et al, 2002; Hsieh et al, 2010) and comparable to biodosimetric analysis by fluorescence in situ hybridisation of stable chromosomal translocation frequencies (Hsieh et al, 1999). The average, median, and range of excess cumulative exposures above background radiation were $48 \mathrm{mGy}, 6.3 \mathrm{mGy}$, and $<1 \sim 2363 \mathrm{mGy}$.

The initial age of exposure (IAE), when the exposed subjects moved into or were born in these buildings, was $16.9 \pm 16.5$ (mean \pm 1 s.d.) years, ranging from 0 to 87 years old, and was much younger than most of the other radiation cohort studies. Significantly increased risks of leukaemia, excluding chronic lymphocytic leukaemia, were reported previously (Hwang et al, $2006,2008)$. The current study further examined the magnitude of site-specific cancers risks, resulting from protracted radiation exposure and distinguished IAEs as contributing factor for cancer induction.

\section{MATERIALS AND METHODS}

A total of 300 cancer cases were reported between 1983 and the end of 2012 through the countrywide National Cancer Registration systems among the 6242 cohort members. These included 247 cancer cases incident after a minimum latent period of 2 years for leukaemia and 10 years for solid cancers (ICRP, 1990; Hwang et al, 2006, 2008). For solid cancers, an alternative minimum latent period of 5 years was also used for sensitive analysis.
The mandatory cancer case report with pathological proof had been established in Taiwan since 1979, with health data accessable by Center of Health Information Application in Taiwan's Ministry of Health and Welfare. The RCB cohort was linked by personal identification number with the Taiwan Cancer Registry (Taiwan Cancer Registry Center, 2017) and the national database of Causes of Death. The study received ethical approval by the TMU-IRB review board.

The attained age was defined when they were diagnosed with a cancer or their age at the last follow-up or at 31 December 2012. With the sparse data for specific cancers during the follow-up period, the analysis of excess relative risk (ERR) by Cox model (hazard ratios; HR) could be more conservative than by the more unstable Poisson linear relative risk model and Poisson model (rate ratios). The $\mathrm{ERR}_{100 \mathrm{mSv}}$ were then calculated by subtracting 1 from $H_{100 \mathrm{mSv}}$, and the HRs from each $100 \mathrm{mSv}, \mathrm{HR}_{100 \mathrm{mSv}}$, were estimated for the association between cumulative exposure (as continuous variables) and related cancer risks by Cox proportional hazard models, adjusting the IAE, individual exposure via TCD, and the 'attained age' as the time scale. To examine the contribution of IAE to risk of breast cancers, Cox models were stratified by IAE $>$ or $\leqslant 20$ years of age. Firth's penalised likelihood estimator was further used for cancer types with less than 10 incidents (Lin et al, 2013). The confidence intervals for site-specific cancers were partial likelihood-based or Firth's penalised likelihood-based for small numbers of events. A test was considered statistically significant if its two-tailed $P$-value was $<0.10$; this was equivalent to a threshold for a one-sided $P$-value $<0.05$ to test for an increased risk.

\section{RESULTS}

The distribution of the subjects with the solid cancers and leukaemia excluding chronic lymphocitic leukaemia (CLL) or multiple myeloma (MM), sex and age at initial exposure, cumulative exposure (TCD, mSv) were shown in Table 1. A total of 236 solid cancers were reported and 11 leukaemia within 97106 person years among the 6242 subjects. The crude solid cancer incidence rate in female $\left(25.38 / 10^{4}\right.$ person-year) was higher than male $\left(23.1 / 10^{4}\right.$ person-year), but reverse result observed in leukaemia (1 vs $0.51 / 10^{4}$ person-year). Increased incidence rate by age at initial exposure and TCD were observed. Assuming minimum latent period 10 years for solid cancer and 2 year for

Table 1. Characteristics of the cohort population in radio-contaminated buildings (RCB cohort) by solid cancers and leukaemia

\begin{tabular}{|c|c|c|c|c|c|c|c|c|}
\hline \multirow[b]{2}{*}{ Characteristics } & \multirow[b]{2}{*}{$\begin{array}{c}\text { No. of subjects } \\
(\%)\end{array}$} & \multirow[b]{2}{*}{$\begin{array}{l}\text { No. of } \\
\text { cases }\end{array}$} & \multicolumn{3}{|c|}{ Solid cancers } & \multicolumn{3}{|c|}{ Leukaemia } \\
\hline & & & $\begin{array}{l}\text { Cancer } \\
\text { cases }^{a}\end{array}$ & $\begin{array}{l}\text { Person- } \\
\text { years }\end{array}$ & $\begin{array}{c}\text { Incidence } \\
\text { rate }^{a}\end{array}$ & $\begin{array}{l}\text { Cancer } \\
\text { cases }^{a}\end{array}$ & $\begin{array}{l}\text { Person- } \\
\text { years }\end{array}$ & Incidence rate ${ }^{a}$ \\
\hline Overall & $6242(100)$ & 247 & 236 & 97106 & 24.3 & 11 & 147984 & 0.74 \\
\hline $\begin{array}{l}\text { Sex } \\
\text { Male } \\
\text { Female }\end{array}$ & $\begin{array}{l}2968(47.5) \\
3274(52.5)\end{array}$ & $\begin{array}{l}113 \\
134\end{array}$ & $\begin{array}{l}106 \\
130\end{array}$ & $\begin{array}{l}45890 \\
51216\end{array}$ & $\begin{array}{l}23.1 \\
25.38\end{array}$ & $\begin{array}{l}7 \\
4\end{array}$ & $\begin{array}{l}69849 \\
78135\end{array}$ & $\begin{array}{l}1.00 \\
0.51\end{array}$ \\
\hline $\begin{array}{l}\text { Age at initial exposure (years) } \\
\quad<20 \\
20-39 \\
\geqslant 40 \\
\text { Mean; median (range) }\end{array}$ & $\begin{aligned} 3907 & (62.6) \\
1721 & (27.6) \\
614 & (9.8) \\
16.9 ; & 9.7(<0-87)\end{aligned}$ & $\begin{array}{r}43 \\
112 \\
92\end{array}$ & $\begin{array}{r}40 \\
108 \\
88\end{array}$ & $\begin{array}{r}58778 \\
29614 \\
8714\end{array}$ & $\begin{array}{r}6.81 \\
36.47 \\
100.99\end{array}$ & $\begin{array}{l}3 \\
4 \\
4\end{array}$ & $\begin{array}{l}90191 \\
43979 \\
13814\end{array}$ & $\begin{array}{l}0.33 \\
0.91 \\
2.90\end{array}$ \\
\hline $\begin{array}{l}\text { Cumulative exposure (Taiwan } \\
\text { Cumulative Dose; mSv) } \\
\quad<5 \\
5-99 \\
\geqslant 100 \\
\text { Mean; median (range) }\end{array}$ & $\begin{array}{c}2932(47.0) \\
2752(44.1) \\
558(8.9) \\
47.7 ; 6.3(<1 \sim 2363) \\
\end{array}$ & $\begin{array}{r}79 \\
122 \\
46\end{array}$ & $\begin{array}{r}79 \\
114 \\
43\end{array}$ & $\begin{array}{r}41671 \\
46137 \\
9298\end{array}$ & $\begin{array}{l}18.96 \\
24.71 \\
46.25\end{array}$ & $\begin{array}{l}0 \\
8 \\
3\end{array}$ & $\begin{array}{l}65448 \\
68620 \\
13916\end{array}$ & $\begin{array}{l}0 \\
1.17 \\
2.16\end{array}$ \\
\hline
\end{tabular}


Table 2. Adjusted hazard ratio associated with a 100-mSv increase in cumulative exposure

\begin{tabular}{|c|c|c|c|c|c|c|c|c|}
\hline \multirow[b]{2}{*}{ Cancer site } & \multicolumn{4}{|c|}{$\begin{array}{l}\text { Minimum latent period } 10 \text { years assumed for solid } \\
\text { cancer and } 2 \text { years for leukaemia }\end{array}$} & \multicolumn{4}{|c|}{$\begin{array}{c}\text { Minimum latent period } 5 \text { years assumed for solid } \\
\text { cancer and } 2 \text { years for leukaemia }\end{array}$} \\
\hline & Case $^{a}$ & $\mathrm{HR}_{100 \mathrm{mSv}}{ }^{\mathrm{b}}$ & $90 \% \mathrm{Cl}^{\mathrm{b}}$ & $P$-value ${ }^{\mathrm{b}}$ & Case $^{a}$ & $\mathrm{HR}_{100 \mathrm{mSv}}{ }^{\mathrm{b}}$ & $90 \% \mathrm{Cl}^{\mathrm{b}}$ & $P$-value ${ }^{b}$ \\
\hline All cancers excluding leukaemia & 241 & 1.04 & $(1.00,1.08)$ & 0.08 & 274 & 1.04 & $(1.00,1.08)$ & 0.05 \\
\hline All solid cancers & 236 & 1.04 & $(1.00,1.08)$ & 0.07 & 269 & 1.04 & $(1.01,1.08)$ & 0.04 \\
\hline Female breast & 35 & 1.11 & $(1.05,1.20)$ & 0.008 & 40 & 1.12 & $(1.04,1.17)$ & 0.002 \\
\hline Thyroid gland & 20 & 1.06 & $(0.83,1.17)$ & 0.52 & 25 & 1.03 & $(0.80,1.15)$ & 0.75 \\
\hline Liver & 18 & 1.05 & $(0.88,1.15)$ & 0.52 & 19 & 1.04 & $(0.88,1.14)$ & 0.57 \\
\hline Stomach & 13 & 1.08 & $(0.92,1.19)$ & 0.27 & 15 & 1.10 & $(0.97,1.19)$ & 0.10 \\
\hline Rectum & 16 & 1.03 & $(0.73,1.17)$ & 0.78 & 17 & 1.02 & $(0.71,1.16)$ & 0.87 \\
\hline Leukaemia excluding MM\&CLL & 8 & 1.18 & $(1.04,1.28)$ & 0.006 & 8 & 1.18 & $(1.04,1.28)$ & 0.006 \\
\hline
\end{tabular}

Table 3. Relative hazards (HRs) of breast cancers by the initial age of exposure

\begin{tabular}{|c|c|c|c|c|c|c|}
\hline Risk groups & Cases & Person years & Incidence (10000 py) & HR & $90 \% \mathrm{Cl}$ of $\mathrm{HR}$ & $P$-value \\
\hline \multicolumn{7}{|l|}{ IAE $>20$ years old } \\
\hline TCD $<5 \mathrm{mSv}$ & 10 & 14131 & 7.1 & 1 & & \\
\hline TCD 5-100 mSv & 11 & 19816 & 5.6 & 0.88 & $0.43,1.82$ & 0.76 \\
\hline $\mathrm{TCD} \geqslant 100 \mathrm{mSv}$ & 7 & 5123 & 13.7 & 2.07 & $0.89,4.62$ & 0.14 \\
\hline TCD $100 \mathrm{mSv}$ (test for linear trend) & & & & 1.07 & $0.98,1.14$ & 0.14 \\
\hline \multicolumn{7}{|l|}{ IAE $\leqslant 20$ years old } \\
\hline TCD $<5 \mathrm{mSv}$ & 1 & 27829 & 0.4 & 1 & & \\
\hline TCD 5-100 mSv & 4 & 26792 & 1.5 & 3.02 & $0.59,31.82$ & 0.33 \\
\hline $\mathrm{TCD} \geqslant 100 \mathrm{mSv}$ & 2 & 4321 & 4.6 & 10.91 & $1.55,125.9$ & 0.05 \\
\hline TCD $100 \mathrm{mSv}$ (test for linear trend) & & & & 1.38 & $1.14,1.60$ & 0.0008 \\
\hline
\end{tabular}

Abbreviations: $\mathrm{Cl}=$ confidence interval; $\mathrm{HR}=$ Hazards ratio; $\mathrm{IAE}=$ initial age at exposure; $\mathrm{TCD}=$ Taiwan Cumulative Dose; person-years accounted for minimum latent periods as stated in Table 2. Breast cancers with minimum latent periods 10 years.

leukaemia and MM, significantly increased risks were observed for leukaemia excluding $\mathrm{MM}$ and chronic lymphocytic leukaemia $\left(\mathrm{HR}_{100 \mathrm{mSv}} 1.18\right.$; $90 \%$ CI 1.04-1.28, $P=0.006$; Table 2$)$, leukaemia excluding CCL $\left(\mathrm{HR}_{100 \mathrm{mSv}} 1.15 ; 90 \%\right.$ CI $\left.1.03-1.24, P=0.012\right)$, female breast cancers $\left(\mathrm{HR}_{100 \mathrm{mSv}} 1.11 ; 90 \%\right.$ CI 1.05-1.20, $P=0.008)$, and all cancers $\left(\mathrm{HR}_{100 \mathrm{mSv}} 1.05 ; 90 \%\right.$ CI $1.01-1.08$, $P=0.04$ ). In addition, assuming shorter latent period of 5 years for solid cancers, increased risk for all solid cancers and lung cancer were noted (Table 2). The $\mathrm{HR}_{100 \mathrm{mSv}}$ for site-specific cancers were all $>1$, with the relative hazards of female breast cancers in different exposure shown in Table 3. For individuals with IAE $\leqslant 20$ years, a dose response increase on breast cancer risk was noted, with $\mathrm{HR}_{100 \mathrm{mSv}} 1.38$ (90\% CI 1.14-1.6; $\left.P=0.0008\right)$. For those IAE $>20$ years, the linear trend was less significant, with $\mathrm{HR}_{100 \mathrm{mGy}}$ 1.07 (90\% CI $0.98-1.14 ; P=0.14$ ).

\section{DISCUSSION}

The follow-up on the cancer risks of this unique cohort extended up to 30 years after their initial radiation exposure. A total 300 cancer cases were collected, with 135 newly reported since the previous report (Hwang et al, 2008). These were mainly consisted of solid cancers and leukaemia and MM.
The cohort population comprised of individuals with a wide range of excessive cumulative exposure, including very low $(<1 \mathrm{mSv})$ and close to unexposed populations. Moreover, the incidence rates were weighted by various durations of observation. Therefore, no parallel appropriate unexposed cohort population was available for comparison. The $\mathrm{HR}_{100 \mathrm{mSv}}$ for leukaemia excluding CLL was 1.18 (ERR ERomSv $_{10.18}, 90 \%$ CI 1.04-1.28), with a smaller standard error estimate than $E R_{100 \mathrm{mSv}} 0.19$ in the previous report (Hwang et al, 2008). On the other hands, the risk estimates for leukaemia were similar to those of the Techa River study $\left(\mathrm{ERR}_{100 \mathrm{mSv}} 0.22\right.$, 95\% CI 0.08-0.54; (Krestinina et al, 2010) and the multi-national nuclear workers study $\left(\mathrm{ERR}_{100 \mathrm{mSv}} 0.19\right.$, 95\% CI <0-0.85 and 0.193; Cardis et al, 2005; Vrijheid et al, 2007), but smaller than the Japanese Life Span Study (LSS) with acute radiation exposure $\left(\mathrm{ERR}_{100 \mathrm{mSv}}\right.$ 0.31; (Preston et al, 1994)) and leukaemia mortality in the INWORKS nuclear workers study $\left(\mathrm{ERR}_{100 \mathrm{mSv}}\right.$ 0.30, 90\% CI 0.12-0.52; (Cardis et al, 2005; Vrijheid et al, 2007)). This could be caused by much lower exposures of this cohort than those of the Techa River with marrow doses up to $9 \mathrm{~Gy}$ and a mean 0.42 Gy (Krestinina et al, 2013), the LSS cohort, and similar to those of the nuclear workers.

As the members of the exposed cohort in Taiwan were not aware of the radiation when they moved in or studied in these buildings, risk factors like cigarette smoking and hormone exposure were assumed randomly occurred and unlikely to 
confound the causal effect of radiation. Moreover, most of these cohorts had relocated to these newly constructed buildings or schools during strong economic development in Taiwan in 1980s, and were likely more socio-economically favorite groups, with less probabilities in adverse health behaviors like cigarette and drinking, compared with the other general public in Taiwan. Therefore, there could be mild under-estimation of the risks incurred in this cohort population.

IAE in the Taiwanese female cohort was relatively young, $16.9 \pm 16.5$ (s.d.) years old (Table 1) and the $\mathrm{ERR}_{100 \mathrm{mSv}}$ for breast cancer was estimated at 0.11 (90\% CI 1.05-1.20) for 10 years latent period (Table 2), similar to the $\mathrm{ERR}_{100 \mathrm{mSv}} 0.12$ (90\% CI $0.07-0.19$ ) in the Japanese LSS cohort, whose ages at exposure were between 10 and 19 years (Preston et al, 2007). On the other hand, age at initial exposure had been demonstrated to be an important effect modifier in relation to the dose response in the LSS study (Land et al, 2003; Preston et al, 2007). In the present study, those who were exposed initially equal or $<20$ years old were shown with a statistically significant radiation dose response and breast cancer risks $\left(\mathrm{HR}_{100 \mathrm{mSv}} 1.38,90 \% \mathrm{CI} 1.14-1.6\right)$, but not those with IAE above 20 years old $\left(\mathrm{HR}_{100 \mathrm{mSv}} 1.07 ; 90 \%\right.$ CI $0.98-1.14$. This suggested that women exposed at younger age were more sensitive to radiation, especially before the age of 20 compared with unexposure population. In either groups of IAE, the incidence rates of breast cancer with exposure $\geqslant 100 \mathrm{mSv}$ were much higher than those $<100 \mathrm{mSv}$. With cigarette smoking rate in women generally below 5\% during the last three decades in Taiwan, and the average incident age of breast cancers 51.7 years old, confounding by smoking or hormonal effect was very unlikely.

The ERR100mSv of all solid cancers in this cohort was $\sim 0.05$, similar to the 0.06 (95\% CI $0.004-0.127$ ) of the Techa River study (Schonfeld et al, 2013) and 0.047 (90\% CI 0.04-0.05; 95\% CI 0.039-0.055; Preston et al, 2007; Grant et al, 2017) of the LSS. In the present study, all point estimates of $H_{100 m S v}$ in site-specific cancers were consistently $>1$.

This suggested that when individuals were exposed at younger ages, the risks of developing breast cancers or solid cancers were similar for acute or chronic radiation exposure. Although the comparisons between protracted and acute exposure studies are a bit complicated. The exact magnitude of effects might not be fully comparable, however, the trends are noteworthy. A stronger dose response in breast cancer risks for the individuals with younger IEA $(P<0.001)$ than those with older IEA $(P=0.14)$ was noted, and was comparable with those by acute exposure.

With small numbers of leukaemia cases in this analysis, the sample size was not adequate to provide stratified analysis on their IAE. Although with relatively small numbers of cancer cases, as a relatively young study population, follow-up of this cohort will provide more results in the future.

In conclusion, the exposed cohort provided unique evidences of protracted, low-dose-rate radiation exposures, with cumulative exposure mostly $<1 \mathrm{~Sv}$. The estimates of the ERR for leukaemia were similar to the Techa River study, as well as to the 15-country nuclear workers' study, but are less than those of the LSS. On the other hand, the estimates of ERR for breast cancer were similar to the LSS among those exposed at ages 10-19. Those who were initially exposed before 20 years old had the highest relative risk of developing breast cancer.

\section{ACKNOWLEDGEMENTS}

This study was supported in part by a research grant from Taiwan's Ministry of Science and Technology, by the Taiwan Ministry of Education through 'the Aim for the Top University plan' of National Yang-Ming University, by Health and Welfare Data Science Center,
Ministry of Health and Welfare, and by the National Association for Radiation Protection, Taiwan. Yu-Shan Cheng had helped in this study in the Table 2, leukaemia cancer analysis.

CONFLICT OF INTEREST

The authors declare no conflict of interest.

\section{REFERENCES}

Cardis E, Vrijheid M, Blettner M, Gilbert E, Hakama M, Hill C, Howe G, Kaldor J, Muirhead CR, Schubauer-Berigan M, Yoshimura T, Bermann F, Cowper G, Fix J, Hacker C, Heinmiller B, Marshall M, Thierry-Chef I, Utterback D, Ahn YO, Amoros E, Ashmore P, Auvinen A, Bae JM, Solano JB, Biau A, Combalot E, Deboodt P, Diez Sacristan A, Eklof M, Engels H, Engholm G, Gulis G, Habib R, Holan K, Hyvonen H, Kerekes A, Kurtinaitis J, Malker H, Martuzzi M, Mastauskas A, Monnet A, Moser M, Pearce MS, Richardson DB, Rodriguez-Artalejo F, Rogel A, Tardy H, Telle-Lamberton M, Turai I, Usel M, Veress K (2005) Risk of cancer after low doses of ionising radiation-retrospective cohort study in 15 countries. BMJ 331: 77.

Chang WP (1993) Spread of Taiwan's radiation panic. Lancet 342: 1544.

Chang WP, Chan CC, Wang JD (1997) 60Co contamination in recycled steel resulting in elevated civilian radiation doses: causes and challenges. Health Phys 73: 465-472.

Chang WP, Kau J (1993) Taiwan: exposure to high doses of radiation. Lancet 341: 750 .

Davis FG, Yu KL, Preston D, Epifanova S, Degteva M, Akleyev AV (2015) Solid cancer incidence in the techa river incidence cohort: 1956-2007. Radiat Res 184: 56-65.

Grant EJ, Brenner A, Sugiyama H, Sakata R, Sadakane A, Utada M, Cahoon EK, Milder CM, Soda M, Cullings HM, Preston DL, Mabuchi K, Ozasa K (2017) Solid cancer incidence among the life span study of atomic bomb survivors: 1958-2009. Radiat Res 187: 513-537.

Hsieh WA, Deng W, Chang WP, Galvan N, Owens CL, Morrison DP, Gale KL, Lucas JN (1999) Alpha coefficient of dose-response for chromosome translocations measured by FISH in human lymphocytes exposed to chronic $60 \mathrm{Co}$ gamma rays at body temperature. Int J Radiat Biol 75: 435-439.

Hsieh WA, Lin IF, Chang WP, Chen WL, Hsu YH, Chen MS (2010) Lens opacities in young individuals long after exposure to protracted low-doserate $\gamma$ radiation in 60Co-contaminated buildings in Taiwan. Radiat Res 173: $197-204$

Hsu WL, Preston DL, Soda M, Sugiyama H, Funamoto S, Kodama K, Kimura A, Kamada N, Dohy H, Tomonaga M, Iwanaga M, Miyazaki Y, Cullings HM, Suyama A, Ozasa K, Shore RE, Mabuchi K (2013) The incidence of leukaemia, lymphoma and multiple myeloma among atomic bomb survivors: 1950-2001. Radiat Res 179(3): 361-382.

Hwang SL, Guo HR, Hsieh WA, Hwang JS, Lee SD, Tang JL, Chen CC, Chang TC, Wang JD, Chang WP (2006) Cancer risks in a population with prolonged low dose-rate gamma-radiation exposure in radiocontaminated buildings, 1983-2002. Int J Radiat Biol 82: 849-858.

Hwang SL, Hwang JS, Yang YT, Hsieh WA, Chang TC, Guo HR, Tsai MH, Tang JL, Lin IF, Chang WP (2008) Estimates of relative risks for cancers in a population after prolonged low-dose-rate radiation exposure: a followup assessment from 1983 to 2005. Radiat Res 170: 143-148.

ICRP (1990) Recommendations on the International Commission on Radiological Protection Vol. 21Pergamon Press: Oxford, UK.

Krestinina L, Preston D, Davis F, Epifanova S, Ostroumova E, Ron E, Akleyev A (2010) Leukemia incidence among people exposed to chronic radiation from the contaminated Techa River, 1953-2005. Radiat Environ Biophys 49: 195-201.

Krestinina LY, Davis FG, Schonfeld S, Preston DL, Degteva M, Epifanova S, Akleyev AV (2013) Leukaemia incidence in the Techa River Cohort: 19532007. Br J Cancer 109: 2886-2893.

Land CE, Tokunaga M, Koyama K, Soda M, Preston DL, Nishimori I, Tokuoka S (2003) Incidence of female breast cancer among atomic bomb survivors, Hiroshima and Nagasaki, 1950-1990. Radiat Res 160: 707-717.

Leuraud K, Richardson DB, Cardis E, Daniels RD, Gillies M, O'Hagan JA, Hamra GB, Haylock R, Laurier D, Moissonnier M, Schubauer-Berigan MK, 
Thierry-Chef I, Kesminiene A (2015) Ionising radiation and risk of death from leukaemia and lymphoma in radiation-monitored workers (INWORKS): an international cohort study. Lancet Haematol 2: e276-e281.

Lin IF, Chang WP, Liao YN (2013) Shrinkage methods enhanced the accuracy of parameter estimation using Cox models with small number of events. J Clin Epidemiol 66: 743-751.

Ozasa K, Shimizu Y, Suyama A, Kasagi F, Soda M, Grant EJ, Sakata R, Sugiyama H, Kodama K (2012) Studies of the mortality of atomic bomb survivors, report 14, 1950-2003: an overview of cancer and noncancer diseases. Radiat Res 177: 229-243.

Preston DL, Ron E, Tokuoka S, Funamoto S, Nishi N, Soda M, Mabuchi K, Kodama K (2007) Solid cancer incidence in atomic bomb survivors: 19581998. Radiat Res 168: 1-64.

Preston DL, Kusumi S, Tomonaga M, Izumi S, Ron E, Kuramoto A, Kamada N, Dohy H, Matsui T, Nonaka H, Thompson DE, Soda M, Mabuchi K (1994) Cancer incidence in atomic bomb survivors. Part III. Leukemia, lymphoma and multiple myeloma, 1950-1987. [erratum appears in Radiat Res 1994;139(1): 129]. Radiat Res 137: S68-S97.

Richardson DB, Cardis E, Daniels RD, Gillies M, O’Hagan JA, Hamra GB, Haylock R, Laurier D, Leuraud K, Moissonnier M, Schubauer-Berigan MK, Thierry-Chef I, Kesminiene A (2015) Risk of cancer from occupational exposure to ionising radiation: retrospective cohort study of workers in France, the United Kingdom, and the United States (INWORKS). BMJ 351: h5359.
Schonfeld SJ, Krestinina LY, Epifanova S, Degteva MO, Akleyev AV, Preston DL (2013) Solid cancer mortality in the techa river cohort. (1950-2007). Radiat Res 179: 183-189.

Taiwan Cancer Registry Center (2017) (http://tcr.cph.ntu.edu.tw/ main.php?Page=N1).

Vrijheid M, Cardis E, Blettner M, Gilbert E, Hakama M, Hill C, Howe G, Kaldor J, Muirhead CR, Schubauer-Berigan M, Yoshimura T, Ahn YO, Ashmore P, Auvinen A, Bae JM, Engels H, Gulis G, Habib RR, Hosoda Y, Kurtinaitis J, Malker H, Moser M, Rodriguez-Artalejo F, Rogel A, Tardy H, Telle-Lamberton M, Turai I, Usel M, Veress K (2007) The 15 -country collaborative study of cancer risk among radiation workers in the nuclear industry: design, epidemiological methods and descriptive results. Radiat Res 167: 361-379.

Wang JC, Lin YP, Hwang SL, Hsieh WA, Chen JC, Tang JL, Hwang JS, Lu WJ, Chang WP (2002) Late haematological changes in population with chronic low dose-rate radiation exposure during childhood. $\mathrm{Br} J$ Radiol 75: 135-140.

This work is published under the standard license to publish agreement. After 12 months the work will become freely available and the license terms will switch to a Creative Commons AttributionNonCommercial-Share Alike 4.0 Unported License. 